\title{
Thermo-tolerance characterization and bioassay of selected entomopathogenic fungal (EPF) isolates on larva of Spodoptera litura Fab.
}

\section{S. Deepak*}

Department of Agricultural Entomology, Agricultural College, Raichur (Karnataka), India A. G. Sreenivas

Department of Agricultural Entomology, Agricultural College, Raichur (Karnataka), India Basavaraj Kalmath

Department of Agricultural Entomology, Agricultural College, Bheemarayanagudi (Karnataka), India

\section{S. G. Hanchinal}

Department of Agricultural Entomology, Agricultural College, Raichur (Karnataka), India

K. T. Vendan

Department of Agricultural Microbiology, Agricultural College, Raichur (Karnataka), India S. S. Patil

Department of Horticulture, Agricultural College, Raichur (Karnataka), India

${ }^{*}$ Corresponding author. E-mail: deepaksihimoge@gmail.com

\begin{abstract}
Entomopathogenic fungi viz. Metarizhium anisoplae and Beauveria bassiana are well characterized in respect to pathogenicity to several insects and have been used for biological control of agriculture pests worldwide. Despite their potential, several factors like low resistance to elevated temperature have hindered widespread adoption of fungi as part of biological control regimes. In this study, five isolates of $B$. bassiana $(\mathrm{Bb} 01, \mathrm{Bb} 02$, $\mathrm{Bb} 03, \mathrm{Bb} 04$ and $\mathrm{Bb} \mathrm{05}$ ) and two isolates of $\mathrm{M}$. anisoplae (Ma 01 and $\mathrm{Ma} 02$ ) were evaluated for thermotolerance capacity and bioefficacy against third instar of Spodoptera litura. Among the isolates studied, $\mathrm{Bb} 04$ recorded the higher temperature tolerance up to $34^{\circ} \mathrm{C}$ with mean spore germination of 35.00 percent and mean dry mycelial weight of 443.38 mg. Further, in the bioassay studies, Bb 04 caused significantly (@ $\mathrm{P}<0.01 \%)$ higher percent mortality of $S$. litura larva at $1 \times 10^{8}$ spores $\mathrm{ml}^{-1}$ on fifth day $(80.00 \%)$ with $\mathrm{LT}_{50}$ value of 4.08 days and $\mathrm{LC}_{50}$ value of $2.07 \times 10^{4}$ conidia $\mathrm{ml}^{-1}$ at five days. Investigation results indicated that BB 04 is a suitable EPF isolate for management of $S$. litura where higher temperature prevails.
\end{abstract}

Keywords: Beauveria bassiana, bioassay, Metarizhium anisoplae, Spodoptera litura, Thermo-tolerance

\section{INTRODUCTION}

Over reliance on broad spectrum pesticides has been severely condemned in different parts of the world after International Conference on Chemicals Management (Tscharntke et al., 2005). Since then, an alternative eco-friendly strategy for the management of noxious insect pests has been explored to trim down the harmful effects of chemical insecticides on humanity. Studies on biodiversity in agro-ecosystems and the delivery of ecosystem services to agricultural products have usually ignored the contribution of entomopathogens in the regulation of pest population. In recent years, biological control based on crop protection with the inundative release of natural enemies and entomopathogens viz., fungi, bacteria, virus etc., are recognized as a valuable tool in pest manage-

\section{Article Info}

DOI: 10.31018/jans.v11i1.2007

Received: February 11, 2019

Revised: February 25, 2019

Accepted: February 27, 2019

\section{How to Cite}

Deepak, S. et al. (2019).

Thermo-tolerance characterization and bioassay of selected entomopathogenic fungal (EPF) isolates on larva of Spodoptera litura Fab. Journal of Applied and Natural Science, 11 (1): $182-187$ 
Despite their potential, several factors have hindered widespread adoption of fungi as part of biological control regimes. In particular, efficacy against certain insects is impeded by the relatively low resistance to elevated temperatures (Rangel et al., 2008). The optimal temperatures for the development of pathogenicity in most entomopathogenic fungi are $25-28^{\circ} \mathrm{C}$. Most previous studies on temperature tolerance of entomopathogenic fungi involved selection of isolates with higher tolerance to extreme environmental temperatures in the field (Rangel et al., 2005). Therefore, the current investigation was formulated to evaluate thermo-tolerance capacity and bioassay potential of selected entontomopathogenic fungal isolates on third instar of Spodoptera litura.

\section{MATERIALS AND METHODS}

Isolates collection: Seven EPF isolates were collected from different Agricultural Colleges of Karnataka, of which five were $B$. bassiana isolates and two were $M$. anisopliae (Table 1). This was a part of doctoral study conducted in Department of Agricultural Entomology, University of Agricultural Sciences, Raichur (Karnataka) during 2014-15 and 2015-16.

Morphological characterization: EPF isolates were cultured on Potato Dextrose Agar (PDA) media in petriplates and incubated at $25^{\circ} \mathrm{C}$ in the dark for two weeks for mycelial growth and spore production. Then, spores of each EPF isolates were harvested using a loop and placed the spores in one $\mathrm{ml}$ of sterile distilled water containing tween $80(0.01 \%)$. The concentration of spore suspension was determined by haemocytometer and further it was adjusted to $1 \times 10^{6}$ conidia $/ \mathrm{ml}$ under microscope at 40X magnification. Subsequently, morphological characters of EPF viz., colony colour, shape, conidia diameter and conidia colour of each EPF were recorded separately (Isra' Omar Ahmad, 2011).

Thermo-tolerance characterization: Temperature tolerance capacity of each EPF isolates was determined through spore germination test and dry mycelial weight at temperatures of $25,28,30$, 32 and $34^{\circ} \mathrm{C}$ in incubators.

Spore germination test: Spores were collected from two week old culture using a loop and transferred to a glass vial containing $10 \mathrm{ml}$ of sterile distilled water and 0.01 percent Tween 80 . Concentration of spore suspensions of each fungal isolates was adjusted to $10^{6}$ spore $\mathrm{ml}^{-1}$. A volume of $100 \mu \mathrm{l}$ of spore suspension was inoculated and spread over a thin layer of PDA medium in separate petriplates $(3 \mathrm{ml}$ medium per $90 \mathrm{~mm}$ petriplate). After the inoculation, petriplates were sealed with parafilm and incubated at temperatures of $25,28,30,32$ and $34^{\circ} \mathrm{C}$ for $24 \mathrm{hrs}$. After the $24 \mathrm{hrs}$ of incubation, a total number of 100 spores were chosen at random from different fields of the petriplate to count the number of germinated spores under compound microscope at the magnification of 40X. (A spore was considered germinated, if the germ tube length reached at least the length of the conidium). The spore counting was performed in four replicates for each isolate and for each temperature.

Dry mycelial weight: Mycelial disc of five $\mathrm{mm}$ size was cut from seven days old actively grown fungal culture and inoculated separately into conical flasks containing Potato Dextrose Broth (Each $50 \mathrm{ml}$ conical flask containing $30 \mathrm{ml}$ broth). For each isolate at each temperature, four replicates were maintained. Flasks were incubated at temperatures of $25,28,30,32$ and $34^{\circ} \mathrm{C}$ for eight days. After eight days of incubation, the mycelial growth was harvested and dried at $70^{\circ} \mathrm{C}$ for $24 \mathrm{hrs}$ in hot air oven. Further, the dry weights were recorded using electronic digital balance in four replicates for each treatment and the average mycelial dry weight was calculated.

Rearing and maintenance of $S$. litura culture: Mass rearing of $S$. litura was initiated in the growth chambers of the laboratory with freshly laid egg masses collected from the fields of Agricultural College, Raichur. Growth chamber was sterilized with 10 percent formaldehyde prior to establishing the culture. Ambient environmental conditions viz., $27 \pm 1.0^{\circ} \mathrm{C}$ temperature, $75.0 \pm 5.0$ percent relative humidity and $12 \mathrm{~h}$ light: $12 \mathrm{~h}$ dark photoperiod was maintained throughout the rearing. In order to have continuous supply of large number of quality insects, a stock culture of $S$. litura was maintained on leaves of the castor plant, Ricinus communis $L$. The freshly laid egg masses were incubated and maintained in small plastic containers with castor leaves to provide immediate food for the neonates after hatching. First instars neonates hatched from the egg mass were reared in bread boxes $(20 \times 10 \times 10 \mathrm{~cm})$. From the fourth instar onwards, larvae were reared in groups of 50-100 in a plastic tray $(40 \times 30 \times 6 \mathrm{~cm})$. Later larvae were allowed for pupation in moist and loose soil. The pupae were sexed on the fourth day after the sclerotization and hardening of pupal integument with respect to the position of gonopores. Male pupae had gonopore in the form of two kidney shaped bumps with a black slot in the middle of the ninth abdominal sternum and female pupae had gonopore as a black slot located on the eighth abdominal sternum. Adult moths were emerged in seven to eight days. Generally 10-12 pairs of moth were released in insect cages $(45 \times 40 \times 40 \mathrm{~cm})$ for mating and oviposition provided with 10 percent honey solution as food for them. Castor leaves were provided as an ovipositional substrate to the female moth within the cage by dipping their petiole in water containing glass beaker (Seth and Sharma, 2002).

Experiments on thermo-tolerance and bioassay 
were conducted twice. Though there were very little variations found in the generated data during two seasons, they were pooled and statistically analysed and results were presented as hereunder.

Bioassay: Pathogenicity of fungi was determined as the estimated spore concentration required to kill 50 percent of the test insects ( $\mathrm{LC}_{50}$, expressed as conidia $\mathrm{ml}^{-1}$ ), and its virulence was estimated by the median time to death of infected insects $\left(\mathrm{LT}_{50}\right)$ (Thomas and Elkinton, 2004). The fungal isolates which found temperature tolerant in the previous study were subjected for bioassay studies.

Conidial suspensions were prepared by harvesting conidia from two week old sporulating cultures and suspending them in sterile distilled water containing 0.2 percent Tween 80 in $10 \mathrm{ml}$ glass bottles. The conidial suspensions were filtered through several layers of sterilized muslin cloth and discarded the mycelial mats. Then, spore concentrations were quantified using a haemocytometer (Goettel and Inglis, 1997) and were used for pathogenicity studies. The conidial suspension used for the virulence studies was adjusted to a final concentration of $1 \times 10^{8}$ conidia $\mathrm{ml}^{-1}$. For the pathogenicity study, five concentrations of conidia including $1 \times 10^{4}, 1 \times 10^{5}, 1 \times 10^{6}, 1 \times 10^{7}$ and $1 \times 10^{8}$ spore $\mathrm{ml}^{-1}$ were used.

Virulence studies: Pre-starved third instar of $S$. litura were topically sprayed with one $\mathrm{ml}$ of the conidial suspension at $1 \times 10^{8}$ conidia $\mathrm{ml}^{-1}$ of EPF isolate and placed in separate pertiplate containing moistened filter paper. For each isolate four replications containing 20 larvae per replication were maintained. These treated insects were incubated in a growth chamber with temperature of $27 \pm 1^{0} \mathrm{C}$ with $75 \pm 5$ percent relative humidity. The experimental larvae were observed for every $24 \mathrm{hr}$ until death, followed by white mycelial growth on the surface of the cadavers. The total mortality data collected on each day were used for the determination of $\mathrm{LT}_{50}$ using probit analysis(Gurvinder and Padmaja, 2008).

Pathogenicity studies: Different serial dilutions of conidial suspensions viz., $1 \times 10^{4}, 1 \times 10^{5}, 1 \times 10^{6}$, $1 \times 10^{7}$ and $1 \times 10^{8}$ spore $\mathrm{ml}^{-1}$ were prepared in sterile distilled water for promising isolates. Then, twenty third instar of $S$. litura in a petriplate (90 $\mathrm{mm}$ diameter) lined with cabbage leaf disc was sprayed with one $\mathrm{ml}$ of conidial suspension from each concentration per each isolate by potter's tower at pressure of 10 psi. Treated larvae were maintained in insect growth chamber at the temperature of $27.0 \pm 1.0^{\circ} \mathrm{C}$ and relative humidity of $75.0 \pm 5.0$ percent. For each isolate four replications containing twenty larvae per replication was used and similarly, another four replications containing twenty larvae per replication sprayed with sterile distilled water and 0.01 percent tween 80 was used as a control. Mortality was counted daily and the mortality data were corrected using Abbott's formula. The lethal concentration ( $\mathrm{LC}_{50}$ and $\left.\mathrm{LC}_{90}\right)$ was determined by probit analysis. Only those larvae covered with white mycelia and spores were considered to have died as a result of fungal infection (Goettel and Johnson, 1992).

Percent mortality was calculated according to Abbot's (1925) formula:

$\%$ Mortality $=\frac{\text { Mortality }(\%) \text { in treatment }- \text { Mortality }(\%) \text { in control }}{100-\text { Mortality }(\%) \text { in control }} \times 100$ ....Eq.1

Statistical analysis: Data from repeated experiments conducted during 2014-15 and 2015-16 were pooled as ANOVA indicated no significant difference between the experiments. Percentage corrected mortality of the larva was calculated as described by Abbot's (1925). The arcsine transformation was used for normalisation of mortality percentage data before an ANOVA was conducted. Analysis was undertaken on the transformed data and untransformed means \pm SE are presented. Entomopathogenic fungal inoculation rates and time effects, and their interactive effects on mortality percentage data were analyzed using WASP 2.0 (ICAR-Goa institute). When ANOVA was significant, comparisons of relevant means were made using Duncan Multiple Range Test (DMRT) significance test at a significance level of $5 \%$. Lethal time and Lethal concentration were analyzed using SPSS 16.0V. Larvae used in the whole study were of age five days which were hatched from single mass of egg.

\section{RESULTS AND DISCUSSION}

Thermo-tolerance characterization

Spore germination test: There were no significant differences among the EPF isolates with re-

Table 1. Source of entomopathogenic fungal isolates.

\begin{tabular}{llll}
\hline $\begin{array}{l}\text { Entomopathogenic } \\
\text { Fungi }\end{array}$ & $\begin{array}{l}\text { Designation of } \\
\text { the isolates }\end{array}$ & $\begin{array}{l}\text { Isolated } \\
\text { From }\end{array}$ & Area of collection \\
\hline \multirow{4}{*}{ Beauveria bassiana } & $\mathrm{Bb} \mathrm{01}$ & Chrysomelid beetle & GKVK, UAS, Bengaluru \\
& $\mathrm{Bb} \mathrm{02}$ & Sugarcane soil & Channarayapattana, Hassan \\
& $\mathrm{Bb} \mathrm{03}$ & S. litura larvae & GKVK, UAS, Bengaluru \\
& $\mathrm{Bb} \mathrm{04}$ & Lepidopteran larvae & Agriculture College, Bheemarayanagudi \\
& $\mathrm{Bb} \mathrm{05}$ & Groundnut soil & UAHS, Shimoga \\
\multirow{2}{*}{ Metarhizium anisopliae } & $\mathrm{Ma} \mathrm{01}$ & French bean soil & Agriculture College, Chinthamani \\
& $\mathrm{Ma} \mathrm{02}$ & Field bean soil & Hunsuru (Mysore) \\
\hline
\end{tabular}


Deepak, S. et al. / J. Appl. \& Nat. Sci. 11(1): 182-187 (2019)

Table 2. Mean conidial germination of the selected $B$. bassiana and $M$. anisopliae isolates incubated at different temperatures.

\begin{tabular}{|c|c|c|c|c|c|}
\hline \multirow{2}{*}{ EPF isolates } & \multicolumn{5}{|c|}{ Mean number of conidia germinated per 100 conidia at different temperature regimes } \\
\hline & At $25^{\circ} \mathrm{C} / 24 \mathrm{hr}$ & At $28^{\circ} \mathrm{C} / 24 \mathrm{hr}$ & At $30^{\circ} \mathrm{C} / 24 \mathrm{hr}$ & At $32^{\circ} \mathrm{C} / 24 \mathrm{hr}$ & At $34^{\circ} \mathrm{C} / 24 \mathrm{hr}$ \\
\hline $\mathrm{Bb} 01$ & $97.12 \pm 1.18^{a}$ & $94.13 \pm 3.57^{\mathrm{a}}$ & $73.25 \pm 2.06^{\mathrm{a}}$ & $50.13 \pm 1.03^{a}$ & $30.50 \pm 0.40^{c}$ \\
\hline $\mathrm{Bb} 02$ & $95.87 \pm 1.25^{a}$ & $92.88 \pm 2.53^{a}$ & $71.63 \pm 1.38^{a}$ & $50.75 \pm 1.85^{a}$ & $31.75 \pm 0.87^{b}$ \\
\hline $\mathrm{Bb} 03$ & $89.75 \pm 3.12^{\mathrm{a}}$ & $89.75 \pm 2.96^{\mathrm{a}}$ & $64.00 \pm 4.38^{\mathrm{b}}$ & $22.75 \pm 0.87^{\mathrm{b}}$ & $2.38 \pm 0.25^{\mathrm{e}}$ \\
\hline $\mathrm{Bb} 04$ & $92.25 \pm 5.95^{\mathrm{a}}$ & $91.88 \pm 1.75^{a}$ & $74.00 \pm 2.04^{a}$ & $51.13 \pm 1.03^{a}$ & $35.00 \pm 0.71^{a}$ \\
\hline $\mathrm{Bb} 05$ & $92.25 \pm 5.24^{a}$ & $91.25 \pm 3.07^{\mathrm{a}}$ & $64.00 \pm 2.48^{b}$ & $22.88 \pm 1.49^{b}$ & $2.63 \pm 0.85^{\mathrm{e}}$ \\
\hline Ma 01 & $92.12 \pm 3.42^{a}$ & $91.50 \pm 1.73^{a}$ & $61.25 \pm 1.55^{\mathrm{b}}$ & $21.00 \pm 1.91^{b}$ & $2.75 \pm 0.29^{d}$ \\
\hline Ma 02 & $92.87 \pm 2.29^{a}$ & $90.75 \pm 2.63^{a}$ & $56.88 \pm 2.17^{c}$ & $23.00 \pm 1.22^{b}$ & $3.75 \pm 0.29^{\mathrm{e}}$ \\
\hline C.D $(p<0.01)$ & NC & I & 4.94 & 2.79 & 1.16 \\
\hline C.V $(\%)$ & NS & NS & 3.73 & 4.05 & 3.74 \\
\hline
\end{tabular}

* Means followed by the same letter in a column are not significantly different at $P<0.01$

Table 3. Mean mycelial dry weight of the selected $B$. bassiana and $M$. anisopliae isolates incubated at different temperatures.

\begin{tabular}{|c|c|c|c|c|c|}
\hline \multirow{2}{*}{ EPF isolates } & \multicolumn{5}{|c|}{$\begin{array}{l}\text { Mean mycelial dry weight }(\mathrm{mg}) \text { at different temperature regimes at } 8 \text { days of incuba- } \\
\text { tion period }\end{array}$} \\
\hline & At $25^{\circ} \mathrm{C}$ & At $28^{\circ} \mathrm{C}$ & At $30^{\circ} \mathrm{C}$ & At $32^{\circ} \mathrm{C}$ & At $34^{\circ} \mathrm{C}$ \\
\hline Bb 01 & $980.13 \pm 23.28^{a}$ & $943.25 \pm 25.69^{a}$ & $723.13 \pm 08.02^{b}$ & $485.00 \pm 25.34^{b}$ & $429.63 \pm 3.38^{b}$ \\
\hline Bb 02 & $981.38 \pm 15.00^{a}$ & $949.25 \pm 10.90^{a}$ & $738.50 \pm 17.82^{\mathrm{ab}}$ & $527.38 \pm 09.01^{a}$ & $429.62 \pm 4.46^{b}$ \\
\hline Bb 03 & $954.88 \pm 36.37^{a}$ & $948.75 \pm 11.00^{a}$ & $466.25 \pm 20.61^{c}$ & $226.00 \pm 04.97^{\mathrm{C}}$ & $96.00 \pm 2.38^{\mathrm{cd}}$ \\
\hline Bb 04 & $985.50 \pm 38.61^{a}$ & $966.00 \pm 08.64^{a}$ & $759.75 \pm 20.22^{\mathrm{a}}$ & $543.00 \pm 12.09^{a}$ & $443.38 \pm 1.25^{a}$ \\
\hline Bb 05 & $939.25 \pm 41.82^{\mathrm{a}}$ & $925.25 \pm 33.07^{a}$ & $423.88 \pm 08.93^{d}$ & $223.88 \pm 02.39^{c}$ & $103.13 \pm 3.94^{c}$ \\
\hline Ma 01 & $983.88 \pm 10.63^{a}$ & $950.25 \pm 09.07^{a}$ & $483.75 \pm 38.19^{c}$ & $186.25 \pm 14.00^{d}$ & $92.50 \pm 10.80^{d}$ \\
\hline Ma 02 & $979.50 \pm 23.53^{a}$ & $950.50 \pm 13.00^{a}$ & $491.25 \pm 00.32^{c}$ & $198.00 \pm 08.12^{\mathrm{d}}$ & $98.38 \pm 3.06^{\mathrm{cd}}$ \\
\hline C.D $(p<0.01)$ & & & & & 10. \\
\hline C.V (\%) & & NS & 3.47 & 3.78 & 2.09 \\
\hline
\end{tabular}

* Means followed by the same letter in a column are not significantly different at $P<0.01$

Table 4. Median lethal time $\left(\mathrm{LT}_{50}\right)$ of thermo-tolerant $B$. bassiana isolates against $S$. litura larva $\left(1 \times 10^{8}\right.$ conidia/ $\mathrm{ml})$.

\begin{tabular}{|c|c|c|c|c|c|}
\hline \multirow{3}{*}{ EPF isolates } & \multicolumn{5}{|c|}{$\mathrm{LT}_{50}$ values of EPFs } \\
\hline & \multirow{2}{*}{$\begin{array}{l}\mathrm{LT}_{50} \\
\text { (days) }\end{array}$} & \multicolumn{2}{|c|}{ Fiducial limit (95\%) } & \multirow{2}{*}{ Slope } & \multirow{2}{*}{$x^{2}$} \\
\hline & & Lower limit & Upper limit & & \\
\hline $\mathrm{Bb} 01$ & 4.76 & 4.31 & 5.21 & 0.16 & 9.91 \\
\hline Bb 02 & 4.44 & 4.20 & 4.67 & 0.15 & 7.62 \\
\hline $\mathrm{Bb} 04$ & 4.08 & 3.85 & 4.30 & 0.16 & 5.12 \\
\hline
\end{tabular}

Table 5. Mortality of $S$. litura larva exposed to thermotolerant $B$. bassiana isolates at various concentration.

\begin{tabular}{llll}
\hline Concentration & \multicolumn{3}{l}{ Per cent mortality } \\
\cline { 2 - 4 } (conidia per ml) & Bb 01 & Bb 02 & Bb 04 \\
\hline \multirow{2}{*}{$1 \times 10^{4}$} & 40.63 & 40.00 & 46.00 \\
& $(39.58)^{\mathrm{d}}$ & $(39.24)^{\mathrm{e}}$ & $(42.70)^{\mathrm{e}}$ \\
$1 \times 10^{5}$ & 45.00 & 45.00 & 51.88 \\
& $(42.12)^{\mathrm{d}}$ & $(42.12)^{\mathrm{d}}$ & $(46.08)^{\mathrm{d}}$ \\
$1 \times 10^{6}$ & 55.63 & 55.00 & 61.00 \\
& $(48.23)^{\mathrm{c}}$ & $(47.88)^{\mathrm{c}}$ & $(51.36)^{\mathrm{c}}$ \\
$1 \times 10^{7}$ & 61.88 & 65.00 & 69.00 \\
& $(51.87)^{\mathrm{b}}$ & $(53.73)^{\mathrm{b}}$ & $(56.17)^{\mathrm{b}}$ \\
$1 \times 10^{8}$ & 70.00 & 75.00 & 80.75 \\
Control & $(56.79)^{\mathrm{a}}$ & $(60.02)^{\mathrm{a}}$ & $(63.97)^{\mathrm{a}}$ \\
$(0.02 \%$ Tween 80$)$ & $(0.59)^{\mathrm{e}}$ & 0.00 & 0.00 \\
C. D (p<0.01 & 3.59 & 3.15 & $(0.59)^{\mathrm{f}}$ \\
C.V $(\%)$ & 2.63 & 2.31 & 0.70 \\
SEm \pm & 0.87 & 0.76 & 0.78 \\
\hline
\end{tabular}

*Treatments with the same letter are not significantly different, $p<0.01$, Figures in the parentheses are arc sine transformed values, Twenty larvae per each replicates were used spect to mean number of spore germination at the temperatures 25 and $28^{\circ} \mathrm{C}$ where, spore germinations were ranged from 89.75 to 97.12 (Table-2). However, as the temperature was increased, the rate of spore germination declined. At $30^{\circ} \mathrm{C}$, the higher percent spore germination was recorded by the isolate $\mathrm{Bb} 04$ (74.00) as compared to remaining isolates. Similarly at $34^{\circ} \mathrm{C}, \mathrm{Bb} 04$ recorded the higher spore germination of 35.00 percent and lowest spore germination was recorded in $\mathrm{Bb} 03$ of 2.38 percent.

Mean dry mycelial weight test: There were no significant differences in the mean dry mycelial weight among EPF isolates (Table-3) grown at the temperatures 25 and $28^{\circ} \mathrm{C}$. But the dry mycelial weight decreased with the increase in temperature. At $30^{\circ} \mathrm{C}$, the higher mean dry mycelial weight was recorded in the isolate $\mathrm{Bb} 04$ of $759.75 \mathrm{mg}$. Similarly, at $34^{\circ} \mathrm{C}$, higher mean dry mycelial weight was recorded in $\mathrm{Bb} 04$ of $443.38 \mathrm{mg}$ and mean mycelial dry weight recorded to be lowest in 
Table 6. Median lethal concentrations $\left(\mathrm{LC}_{50}\right.$ and $\left.\mathrm{LC}_{90}\right)$ of thermo-tolerant $B$. bassiana isolates against larva of S. litura at various concentrations.

\begin{tabular}{|c|c|c|c|c|c|c|c|c|}
\hline \multirow{2}{*}{$\begin{array}{l}\text { EPF iso- } \\
\text { lates }\end{array}$} & \multirow{2}{*}{$\begin{array}{l}\mathrm{LC}_{50} \\
\text { (conidia/ } \\
\mathrm{ml} \text { ) }\end{array}$} & \multicolumn{2}{|c|}{ Fiducial limit (95\%) } & \multirow{2}{*}{$\begin{array}{l}\mathrm{LC}_{90} \\
\text { (conidia/ml) }\end{array}$} & \multicolumn{2}{|c|}{ Fiducial limit (95\%) } & \multirow[b]{2}{*}{ Slope } & \multirow[b]{2}{*}{$x^{2}$} \\
\hline & & $\begin{array}{l}\text { Lower } \\
\text { limit }\end{array}$ & $\begin{array}{l}\text { Upper } \\
\text { limit }\end{array}$ & & Lower limit & limit & & \\
\hline $\mathrm{Bb} 01$ & $2.45 \times 10^{5}$ & $3.81 \times 10^{4}$ & $1.39 \times 10^{6}$ & $1.38 \times 10^{11}$ & $1.31 \times 10^{9}$ & $3.17 \times 10^{13}$ & 0.28 & 0.30 \\
\hline $\mathrm{Bb} 02$ & $3.11 \times 10^{5}$ & $4.27 \times 10^{4}$ & $8.71 \times 10^{5}$ & $1.02 \times 10^{12}$ & $3.17 \times 10^{10}$ & $2.41 \times 10^{14}$ & 0.28 & 0.24 \\
\hline $\mathrm{Bb} 04$ & $2.07 \times 10^{4}$ & $5.98 \times 10^{3}$ & $2.06 \times 10^{5}$ & $7.95 \times 10^{9}$ & $2.94 \times 10^{8}$ & $6.24 \times 10^{13}$ & 0.29 & 1.07 \\
\hline
\end{tabular}

Ma 01 of $92.50 \mathrm{mg}$.

Unfavorable temperatures are one of the limiting factors of EPF in controlling arthropods. Fungi tolerant to high temperatures are especially important, when fungal isolates are selected for insect pest management in the tropical and subtropical climate. Pathogenicity of most EPF is usually performed at $25-28^{\circ} \mathrm{C}$. However, isolates with optimal growth temperatures below these levels may not be successful for application at the higher temperature $\left(30-35^{\circ} \mathrm{C}\right)$ as shown by Polar et al. (2005). In the current study, Bb 04 recorded the temperature tolerance up to $34^{\circ} \mathrm{C}$ with higher mean spore germination and higher mean dry mycelial weight. It is also evident in the current study that the maximum temperature required for spore germination and mycelial growth was $32^{\circ} \mathrm{C}$ for all the isolates, which was in accordance with that of Walstad et al. (1970) on the B. bassiana and $M$. anisopliae isolates and Fargues et al. (1992) on M. anisopliae isolates.

\section{Bioassay studies}

Estimation of LT $_{50}$ value: Virulence studies were conducted with isolates viz., $\mathrm{Bb} 01, \mathrm{Bb} 02$ and $\mathrm{Bb}$ 04 at the higher spore concentration of $1 \times 10^{8}$. The estimated $\mathrm{LT}_{50}$ values for these three isolates were ranged from 4.08 to 4.76 days (Table - 4). The smallest $\mathrm{LT}_{50}$ value was recorded for $\mathrm{Bb} 04$ of 4.08 days with fiducial limit of 3.85 to 4.30 days and the larger $\mathrm{LT}_{50}$ value was recorded for $\mathrm{Bb} 01$ of 4.76 days with fiducial limit of 4.31 to 5.21 days. The $\mathbf{x}^{2}$ value was 9.91 and 5.12 for $\mathrm{Bb} 01$ and $\mathrm{Bb}$ 04 , respectively.

The estimated $\mathrm{LT}_{50}$ value for $\mathrm{Bb} 04$ was 4.08 days @ $1 \times 10^{8}$ conidia/ml and which was closer to $\mathrm{LT}_{50}$ value of 4.80 and 4.00 days recorded by $\mathrm{Bb} 02$ and $\mathrm{Bb} 09$ isolates of ( $B$. bassiana from Madurai and Dindigul)on $S$. litura larva at $1.5 \times 10^{8}$ conidia/ $\mathrm{ml}$ (Moorthi et al., 2011). Similarly, $\mathrm{LT}_{50}$ value of the current studies were much larger than the $\mathrm{LT}_{50}$ value estimated by Silva et al. (2003) of 1.10 days for $B$. bassiana isolate ESALQ 634 on second instar of Plutella xylostella at $1 \times 10^{8}$ conidia/ml. Virulence of an isolate also depends on the interaction of the host, the pathogen and the environment, where study was done by Santiago et al. (2006) on B. bassiana to Bemisia tabaci reared on cucumber, tomato, melon, green pepper, potato, eggplant, marrow, cabbage, bean or cotton Thomas and Elkinton, 2004 on Entomophaga maimaiga for virulence and Faria and Wraight, (2007) based on compiled report of various entomopathogenic fungal isolates over insects of 48 families.

Percent mortality on fifth day: $B$. bassiana isolates viz., $\mathrm{Bb} 01, \mathrm{Bb} 02$ and $\mathrm{Bb} 04$ caused significantly higher percent mortality of $S$. litura larva at the concentration of $1 \times 10^{8}$ condia $\mathrm{ml}^{-1}$ on fifth day under controlled environmental conditions compared to control (Table - 5). The highest cumulative mortality of 80.75 percent was recorded with $\mathrm{Bb} 04$ isolate where as, $\mathrm{Bb} 01$ resulted in the lowest cumulative mortality of 70.00 percent.

When EPF spores come in contact with cuticle, they germinate and grow directly through it to inner body of larva. Here fungus proliferates inside, produces toxins and nutrients, eventually kills the larva. In the current study, $\mathrm{Bb} 04$ caused significantly higher percent mortality of $S$. litura larva at the concentration of $1 \times 10^{8}$ condia/ml on fifth day. Gupta and Kumar (2014) also reported a mortality of 80.00 percent on third instar of $S$. litura, when $B$. bassaiana applied at concentration of $0.2 \times 10^{8}$ spore/ml.

Estimation of $\mathrm{LC}_{50}$ and $\mathrm{LC}_{90}$ value: The increasing conidial concentration significantly increased larval mortality as shown in the table 6. There were significant differences in percent mortality of S. litura larva at different spore concentration of three tested isolates on five days after treatment. The smallest $\mathrm{LC}_{50}$ and $\mathrm{LC}_{90}$ values were recorded to be $2.07 \times 10^{4}$ and $7.95 \times 10^{9}$ conidia $\mathrm{ml}^{-1}$ with fiducial limit of $5.98 \times 10^{3}$ to $2.06 \times 10^{5}$ and $2.94 \times 10^{8}$ to $6.24 \times 10^{13}$ conidia $\mathrm{ml}^{-1}$, respectively in the isolate $\mathrm{Bb}$ 04. While, the larger $\mathrm{LC}_{50}$ and $\mathrm{LC}_{90}$ values were $3.11 \times 10^{5}$ and $1.02 \times 10^{12}$ conidia $\mathrm{ml}^{-1}$ with fiducial limit of $4.27 \times 10^{4}$ to $8.71 \times 10^{5}$ and $3.17 \times 10^{10}$ to $2.41 \times 10^{14}$ conidia $\mathrm{ml}^{-1}$, respectively in the isolate $\mathrm{Bb} 02$. The $\mathrm{X}^{2}$ values were 0.24 and 1.07 for $\mathrm{Bb} 02$ and $\mathrm{Bb} 04$, respectively.

The estimated $L_{50}$ value of $\mathrm{Bb} 04$ was $2.07 \times 10^{4}$ conidia/ml at five days after treatment. The estimated $L_{50}$ value of current bioassay studies were closer to $\mathrm{LC}_{50}$ value of $2.1 \times 10^{6}$, $3.6 \times 10^{7}$ and $1.2 \times 10^{7}$ conidia/ml on third instar of $S$. litura, registered by $B$. bassiana isolates (from Madurai and Dindigul) viz., Bb 02, Bb 09 and $\mathrm{Bb} 10$, respectively (Moorthi et al., 2011). The difference in pathogenicity between the isolates of current study and experimental isolates of Moorthi et al., 2011 may be due to the susceptibility of larval stages, virulence of EPF isolates used for bioassay and laboratory conditions. 


\section{Conclusion}

Isolates of the same species of $B$. bassiana and $M$. anisoplae varied in their response to elevated temperatures with regard to spore germination and dry mycelial weight. All EPF isolates (Five of $B$. bassiana and two of $M$. anisoplae) were capable to grow at temperatures of $25-32^{\circ} \mathrm{C}$ with apparent differences among isolates in their tolerance to the maximum temperature of $32^{\circ} \mathrm{C}$. At this temperature, $\mathrm{Bb} 04$ showed higher germination rate of 51.13 percent spores and the higher dry mycelial weight of $543.00 \mathrm{mg}$. Subsequently, temperature tolerant EPF isolate, Bb 04 was subjected to bioassay against third instar of $S$. litura, where, $\mathrm{Bb} 04$ showed the higher virulence $\left(\mathrm{LT}_{50}\right)$ and pathogenicity $\left(\mathrm{LC}_{50}\right)$. These results suggested that $\mathrm{Bb} 04$ was a suitable EPF isolate for management of $S$. litura, where hot temperature prevails.

\section{REFERENCES}

1. Abbot's W. S. (1925). A method of computing the effectiveness of an insecticide, J. Econ. Entomol., 18 (2): 265-267.

2. Anand, R. and Tiwary, B. N., (2009), Pathogenicity of entomopathogenic fungi to eggs and larvae of Spodoptera litura, the common cutworm. Biocontrol. Sci. Tech., 19(9): 919-929 DOI: 10.1080/09583150903205069.

3. Fargues, J., Maniania, N. K., Delmas, J. C. and Smits, N., (1992), Influence of temperature on in-vitro growth of entomopathogenic hyphomycetes. Agronomie, 12: 557-564 DOI: 10.1051/agro:19920708.

4. Faria, M. R. and Wraight, S. P., (2007), Mycoinsecticides and mycoacaricides: A comprehensive list with worldwide coverage and international classification of formulation types. Biol. Cont., 43: 237-256 DOI: 10.1016/j.biocontrol.2007.08.001.

5. Goettel, M. S. and Inglis, G. D., (1997), Fungi: hyphomycetes; In Manual of Techniques in Insect Pathology (edited by L. A. Lacey). Academic Press, San Diego. pp. 213-248.

6. Goettel, M.S. and D.L. Johnson (1992) Environmental Impact and Safety of Fungal Biocontrol Agents. In: Biological Control of Locusts and Grasshoppers, Lomer, C.J. and C. Prior (Eds.). CAB International, Wallingford, USA., pp: 356-361 DOI: 10.1146/ annurev.ento.46.1.667.

7. Gupta, S. D. and Kumar, B., (2014), Bioefficacy of Beauveria bassiana (Balsamo) against third instar larvae of Spodoptera litura (Far.), Internat. J. Plant Sci., 9(1): 97-100.

8. Gurvinder Kaur and V. Padmaja. (2008) Evaluation of Beauveria bassiana isolates for virulence against Spodoptera litura (Fab.) (Lepidoptera: Noctuidae) and their characterization by RAPD-PCR, Afr. J. Microbiol. Res., 2 : 299-307.

9. Isra' Omar Ahmad Al_qadi, (2011), Genotyping and Thermotolerance Characterization of Several Isolates of Entomopathogenic Fungi from Palestine, Bethlehem University, Palestine, M.Sc Thesis pp. 24-25.

10.Moorthi, P. V., Balasubramanian, C. and Kubendran, T., 2011, Efficacy of local isolates of Beauveria bassiana against Spodoptera litura (F.) (Lepidoptera: Noctuidae). J. Biol. Cont., 25(1): 22-25 DOI: 10.1186/ s40064-015-1437-1.

11.Nadeau, M. P., Dunphy, G. B. and Boisvert, J. L., (1996), Development of Erynia conica (Zygomycetes: Entomophthorales) on the cuticle of the adult black flies Simulium decorum (Diptera: Simuliidae), J. Invertebr. Pathol., 68: 50-58 DOI:10.1006/ jipa.1996.0057.

12.Polar, P., Muro, M. A., Kairo, M. T., Moore, D., Pegram, R., John, S. A. and Roach B, C., (2005), Thermal characteristics of Metarhizium anisopliae isolates important for the development of biological pesticides for the control of cattle ticks. Vet. Parasitol., 134: 15967 DOI:10.1016/j.vetpar.2005.07.010.

13.Rangel, D. E., Alston, D. G. and Roberts, D. W., (2008), Effects of physical and nutritional stress conditions during mycelial growth on conidial germination speed, adhesion to host cuticle, and virulence of $\mathrm{Me}$ tarhizium anisopliae, an entomopathogenic fungus. Mycol. Res., 112:1355-1361.

14.Rangel, D. E., Braga, G. U., Anderson, A. J. and Roberts, D. W., (2005), Variability in conidial thermotolerance of Metarhizium anisopliae, isolates from different geographic origins. J. Invertebr. Pathol., 88 (2): 116-125 DOI: 10.1016/j.jip.2004.11.007.

15.Rao, C., Devi, K. U. and Khan, P. A. A., (2006), Effect of combination treatment with entomopathogenic fungi Beauveria bassiana and Nomuraea rileyi (Hypocreales) on Helicoverpa armigera (Lepidoptera: Noctuidae). Biocontrol Sci. Technol., 16: 221-232 DOI: 10.1080/09583150500335632.

16.Sandhu, S. S., Sharma, A. K., Beniwal, V., Goel, G., Batra, P., Kumar, A., Jaglan, A. K. Sharma, S. and Malhotra, S., (2012), Myco- Biocontrol of Insect Pests: Factors Involved, Mechanism and Regulation, Journal of Pathogens., Article ID 126819, 10 pages, doi:10.1155/2012/126819.

17.Santiago, A, C., Maranhao, E. A. and Quesada, M, E., (2006), Host plant influences pathogenicity of Beauveria bassiana to Bemisia tabaci and its sporulation on cadavers. Bio Cont., 51: $519-532$ DOI: $10.1007 / \mathrm{s} 10526-005-5737-1$.

18.Seth, R. K. and Sharma, V. P., (2002), Growth, development, reproductive competence and adult behaviour of Spodoptera litura (Lepidoptera: Noctuidae) reared on different diets. Joint FAO/IAEA, Division of Nucl. Techniques (Vienna), 126: 15-22.

19.Silva, V. C. A., Barros, R., Edmilson, J., Jorge, M. E. and Torres, B., (2003), Susceptibility of Plutella $x y$ lostella (L.) (Lepidoptera: Plutellidae) to the fungi Beauveria bassiana (Bals.) Vuill. and Metarhizium anisopliae (Metsch.) Sorok. Neotrop. Entomol., 32(4): 653-658 http://dx.doi.org/10.1590/S1519$566 \times 2003000400016$.

20.Thomas, S. R. and Elkinton, J. S., (2004). Pathogenicity and virulence. J. Invertebr. Pathol., 85: 146151 DOI: 10.1016/j.jip.2004.01.006.

21.Tscharntke, T., Klein, A. M., Kruess, A., Dewenter, I. S. and Thies, C., (2005), Landscape perspectives on agricultural intensification and biodiversity ecosystem service management. Ecol. Lett. 8: 857- 874 DOI:10.1111/j.1461-0248.2005.00782.x.

22.Walstad, J. D., Anderson, R. F. and Stambaugh, W. J., (1970), Effects of environmental conditions on two species of muscardine fungi (Beauveria bassiana and Metarhizium anisopliae). J. Invertebr. Pathol,, 16: 221 -226 DOI: 10.1016/0022-2011(70)90063-7. 